\title{
Development of a picking and dropping mechanism for protray grown vegetable seedlings
}

\section{Vivek Periasamy*}

Department of Farm Machinery \& Power Engineering, AEC \& RI, Tamil Nadu Agricultural University, Coimbatore- 641003 (Tamil Nadu), India

\section{Duraisamy}

Department of Farm Machinery \& Power Engineering, AEC \& RI, Tamil Nadu Agricultural University, Coimbatore- 641003 (Tamil Nadu), India

\section{Kavitha}

Department of Farm Machinery \& Power Engineering, AEC \& RI, Tamil Nadu Agricultural University, Coimbatore- 641003 (Tamil Nadu), India

${ }^{*}$ Corresponding author. Email: vivekagriengg@gmail.com

\section{Article Info}

https://doi.org/10.31018/ jans.v13iSI.2776

Received: March 22, 2021

Revised: April 17, 2021

Accepted: May 8, 2021

\section{How to Cite}

Periasamy, V. et al. (2021). Development of a picking and dropping mechanism for protray grown vegetable seedlings. Journal of Applied and Natural Science, 13 (SI), 47 - 54. https://doi.org/10.31018/jans.v13iSI.2776

\begin{abstract}
In India, manual transplanting of vegetable seedlings was the commonly adopted method for raising vegetable crops, but it is laborious, time-consuming and costly. Therefore, mechanical transplanters are developed to overcome the problems in manual transplanting. The present work was to develop multiple seedlings picking and transferring mechanism for protray grown vegetable seedlings. Tomato (Solanum lycopersicum), chilli (Capsicum annuum) and brinjal (Solanum melongena) seedlings were raised in portrays with coir pith as a growth media and used for transplanting operation. The mechanism was to pick seven numbers of seedlings in one row at a time and transfer them into lateral conveying system, which could deliver the seedlings one by one on to the ground at regular interval. Programmable Logic Controller was used to controlling entire operations of seedlings picking and dropping. At the time of evaluation, a totally 196 number of seedlings were used with 98 cell protray. From the test results, the success rate of 89.28 per cent, missing seedling of 3.57 per cent, damaged seedling of 4.08 per cent, seedling delivering failure of 3.06 per cent were recorded for tomato seedlings.

Similarly, in chilli and brinjal the success rate of 95.40 and 91.83 per cent, the missing seedling of 2.04 and 2.55 per cent, damaged seedling of 1.53 and 3.06 per cent and seedling delivering failure of 1.02 and 2.55 per cent respectively were observed. Transplanting frequency of developed mechanism was 2520 seedlings $\mathrm{h}^{-1}$. As a whole, this work was able to develop a working model of vegetable seedling transplanting mechanism, which can eject seven seedlings at a time from portray cell and transfer them into the slotted conveyor.
\end{abstract}

Keyword: Coir pith, Gripper, Picking mechanism, Protray seedlings, Transplanting rate

\section{INTRODUCTION}

In India, manual transplanting of vegetable seedlings was the commonly adopted method for raising vegetable crops, but it is laborious, time-consuming and costly. Therefore, mechanical transplanters are being developed to overcome the problems in manual transplanting. These transplanters include devices for feeding, conveying and metering a variety of vegetable seedlings. Initially, semiautomatic transplanters were reported as successful for transplanting of vegetable seedlings, but a requirement of a significantly higher amount of labourers to feed the seedlings to the trans- planter could not attract the farmers in India. To overcome the limitations of semi-automatic transplanter, automatic vegetable transplanters were developed. This necessitated developing a suitable mechanism to feed the seedlings to the metering device without any human intervention.

Han et al. (2018) developed multi-task robotic transplanting work cell for greenhouse seedlings. The transplanting system having multi-grippers was designed to automatically pick-up and plant whole rows of seedlings. The conveyors were designed with the pallet-type double-row chain transmission system which moves the plug trays and pots to the predefined working space 
of the multi-grippers. The results was up to $90 \%$ at the efficiency of 960 plants/h.

Yang et al. (2018) developed a seedling separation device with reciprocating movement of seedling cups and the full automatic plug seedling transplanter system. The linear driving motor and driving cylinder were used to control the reciprocating motion, open and close mechanism of mobile seedling cups. It assured the control program for picking of seedling in the fixed position and the transmission of seedling rapidly and dropping of seedling in the fixed position. The results showed that speed and the success rate was 70 working cycles $\mathrm{min}^{-1}$ and 95.03 per cent, respectively.

Although these automatic and robotic transplanters performed well, their complex structure and high manufacturing costs have made it difficult to use a large number of growers. These transplanting systems are not feasible for local plug transplants production since publication of their designs does not match progress made so far in the agronomic technology of seedling production (Rozan et al., 2016). Furthermore, the existing mechanism, can pick and transfer a single seedling at a time. It takes more time to achieve the operations viz., grasping, remove the plug seedling from protray cell, transfer to the specified location and finally release the seedling with low transplanting frequency (Han et al., 2018). Hence, the present study was under taken to reduce the transplanting time to meet the tractor forward speed. For the same, the aim was to develop and evaluate a multiple seedling pickup unit.

\section{MATERIALS AND METHODS}

For the development of an automatic transplanting mechanism for protray grown vegetable seedlings, two stages were considered. The first stage was the automation of seedling removal. Seedlings need to be picked and transferred from the protray one by one without damaging the plug seedling. Since the removal mechanism was difficult in single action, two actions were required. One was grasping the plug seedling with a robotic arm like structure and another action was to remove the plug seedling from the protray cell with the help of pneumatic cylinder. The second stage was automating the conveying of protray seedlings to the picking mechanism. Hence, the entire study was split into two phases. The study was deliberated to develop an effective gripping device at the initial stage, which grasped, removed, and released protray grown seedling without any missing and damaged seedlings. Furthermore, the study was extended to pick seven numbers of seedlings in one row at a time and transfer into lateral conveying system, which could deliver the seedlings one by one on to the ground at regular interval.

The materials used to develop a seedling picking finger and linkage mechanism for gripping the protray raised seedling and methodology adopted for evaluating the finger gripping mechanism are detailed. Further, the development and testing of multiple numbers of seedlings picking and dropping mechanism are explained. The procedure adopted for evaluating the performance of the developed automatic vegetable seedling transplanting mechanism is outlined.

\section{Selection of crop and machine operational parameters to develop a picking mechanism}

Tomato, chilli and brinjal seedlings raised in 98 celled protray were used for conducting experiment. Coir pith and protray cell size $17.83 \mathrm{~cm}^{3}$ were used as it was found suitable for good quality seedlings of all the three vegetables and 25 days age of tomato seedling, 40 days age of chilli and brinjal seedlings were used as it gave minimum damages to seedlings while picking (Kavitha and Duraisamy 2008; Sivakumar and Durairaj, 2014).

Three types of mechanical linkage were developed for the optimized piercing finger and tested in a developed experimental setup to grasp, remove, transfer and release the seedlings. The study was conducted with three levels of media moisture content $(16 \pm 1,18 \pm 1$ and $21 \pm 1$ per cent), three types of picking fingers (sliding plate cam type, sliding end cam type and four bar type picking finger) and three levels of angle of gripper needle $\left(6^{\circ}, 8^{\circ}\right.$ and $\left.10^{\circ}\right)$ for assessing maximum successful ejection and delivering with minimum missing and damages to protray grown selected vegetable seedlings as shown in Fig. 1. (Yang et al., 1991; Kumar
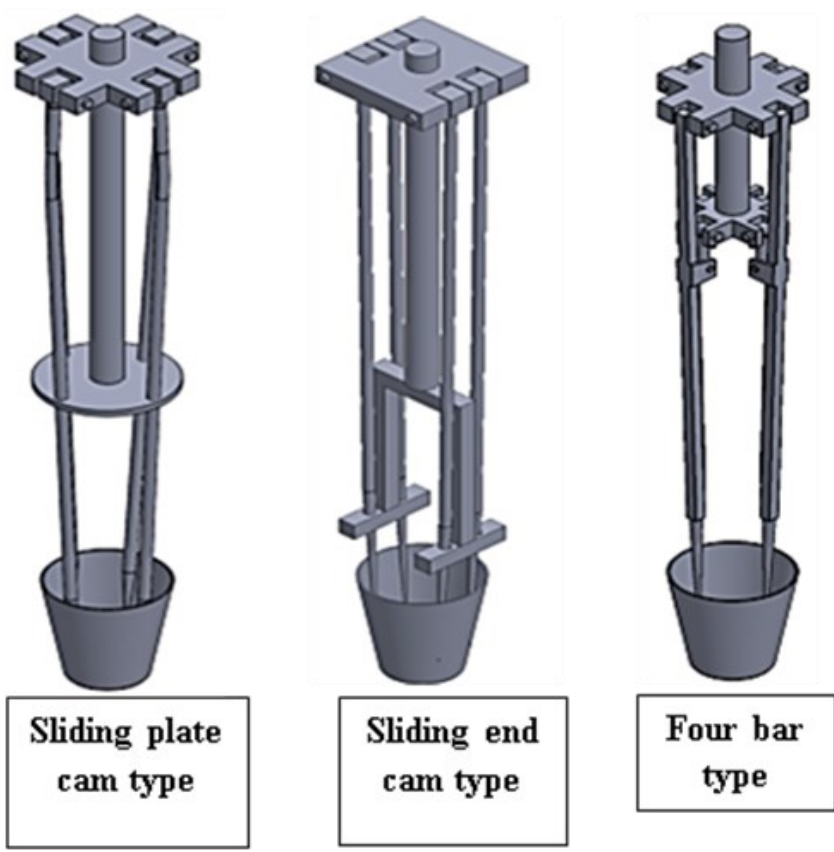

Fig. 1. View of picking fingers for picking of portray grown seedlings. 
and Raheman, 2011; Kang et al., 2012 and Mao et al., 2014).

\section{Experimental setup for evaluate the picking fingers} It consisted of a mainframe, an aluminium linear extrusion frame, linear guideway, linear rail, limit switch, stepper motor with pulleys, timer belt, pneumatic cylinders of $50 \mathrm{~mm}$ and $60 \mathrm{~mm}$ stroke, electrical panel box, solenoid values with coils, Filter Regulator Lubricator (FRL) unit, Switched-Mode Power Supply (SMPS), Programmable logic controller (PLC) board, relay board, stepper drive, conveyor, wiper motor with spire gear and tray guide shaft (Fig. 2). Two pneumatic cylinders actuated the mechanical linkage picking fingers, one to grasp the seedling and another to remove the seedling from protray cell. The same sequence of operation was repeated seven times to pick all seven numbers of seedlings in the first row. Belt conveyer was used to move the protray seedlings to the picking device. PLC was used to control the picking and to transfer the protray seedling.

\section{Protray seedlings conveyer}

Nylon belt conveyor was used for the automatic movement of protray at a regular interval. A 45-rpm wiper motor was used for the operation of the conveyor. After the complete removal of seedlings from the first row of the protray, the conveyor moves one step forward to position the cells of the second row of the protray just below the gripper mechanism. The distance of movement of tray and the time taken for the movement were measured and it was incorporated in the programme. The process was continued to pick the seedlings in the desired position. The transplanting rate was set as 840 seedlings $\mathrm{h}^{-1}$.

\section{Effect of selected levels of variables on assessed parameters}

A total number of 81 experiments were conducted in the automatic picking and dropping mechanism with the selected levels of variables. The test results were used to evaluate the adaptability of the pick-up device. The effect of the selected levels of variables on the measured parameters was statistically analyzed by using AGRES statistical software. The success of ejection or failure was recorded in each replication and data were recorded. A completely randomized design of statistical experiment was done, wherein the response variable is a success or failure over the three independent variables.

\section{Optimization of selected levels of variables for} effective picking and dropping device

The selected levels of variables were optimized for achieving the optimum picking efficiency reflected in terms of success rate with minimum missing and damage to the plug seedlings. The treatment with the combination of selected variables that resulted in maximum

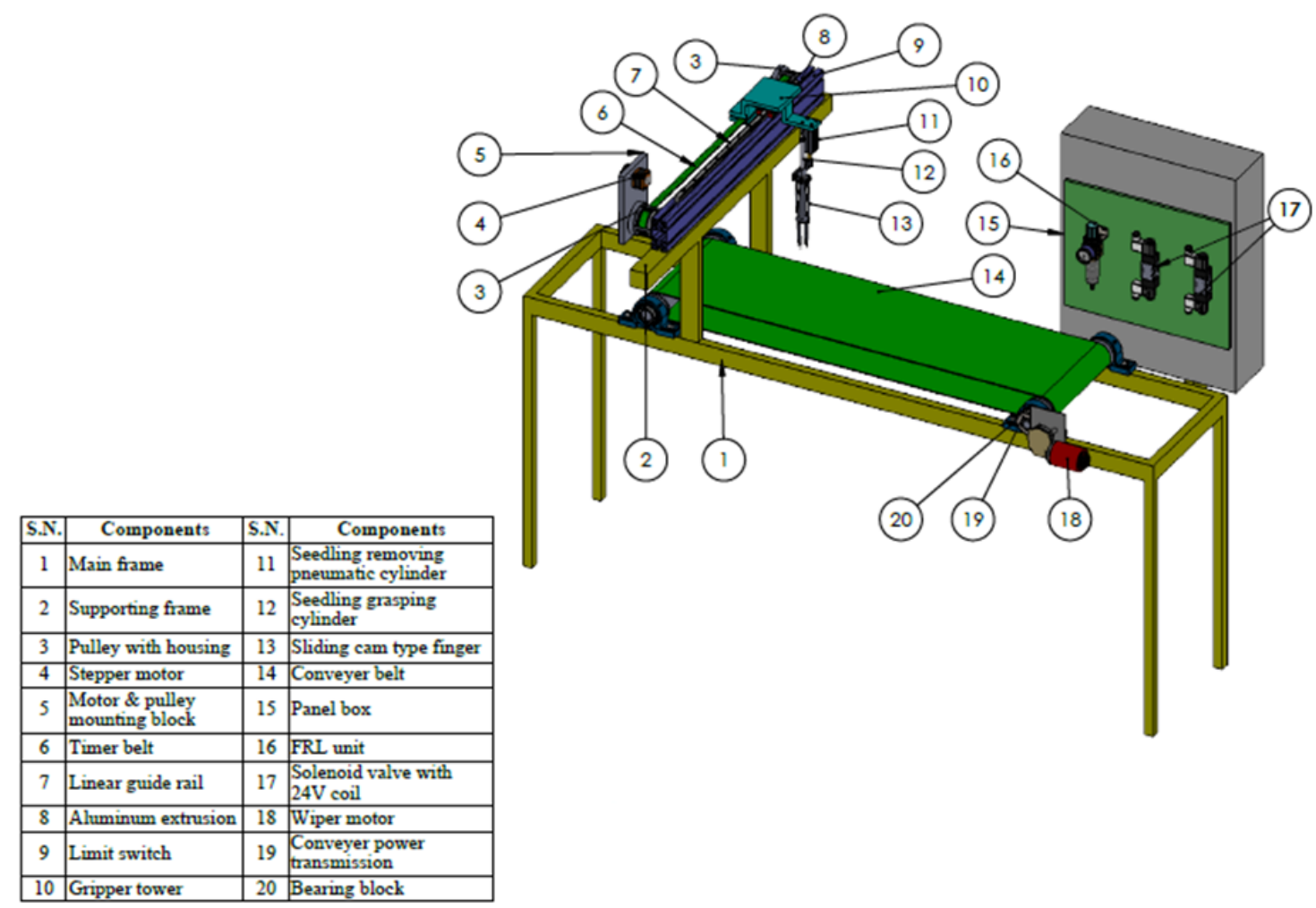

Fig. 2. Experimental setup for evaluating the picking fingers. 
picking efficiency with minimum missing and damage to the plug seedlings with optimized level of age of seedlings for tomato, chilli and brinjal was selected.

\section{Development of multiple seedling picking and transplanting mechanism}

The developed mechanism could pick and transfer a single seedling at a time. It takes 3 seconds to achieve the operations viz., grasping, remove the plug seedling from protray cell, transfer to the specified location and finally release the seedling at a frequency of 840 seedlings $h^{-1}$. Hence, the study was taken up to reduce the transplanting time to meet the tractor forward speed. For the same, a multiple seedling pickup and the transferring unit was developed and evaluated as explained below.

The aim was to pick all seven numbers of seedlings in one row and transfer into lateral conveying mechanism that could deliver the seedlings one by one on to the ground at regular intervals. Hence, a picking mechanism for multiple plug seedlings was developed and its performance was evaluated. It consisted of a mainframe, aluminium arms, pneumatic cylinders, gripping unit, panel box, SMPS, PLC, solid-state relay, solenoid valves with coil, FRL unit, protray conveying mechanism, seedlings conveying mechanism and $24 \mathrm{~V}$ wiper motors. The sliding plate cam- type mechanical linkage-picking finger was used as a gripping device.

The development of multiple seedling picking and the dropping mechanism is shown in Fig. 3. All components of multiple seedlings picking and dropping mechanism for protray grown vegetable seedlings were mounted on the mainframe. The entire gripping unit was threaded to pneumatic cylinder shaft with the help of aluminium plate that helps to remove out the plug seedlings from the protray cell. Seven seedlings from the first row were grasped, removed from protray cell and then transferred into the slotted conveyer with the help of aluminium arms. The length of the aluminium channel was selected based on the gripper picking position to releasing position.

Two belt conveying systems were used in the multiple seedlings picking system from the protray. One was after the removal of seedlings from the first row of the protray. The conveyor moves one step forward to position the cells of the second row of the protray just below the gripper mechanism. The distance of tray movement and the time taken for the movement were measured and incorporated in the programme. In addition, the other for conveying the seedlings for their release by the gripper with lateral conveyer. The operational sequence of multiple seedlings picking and dropping mechanism is shown in Fig. 4.

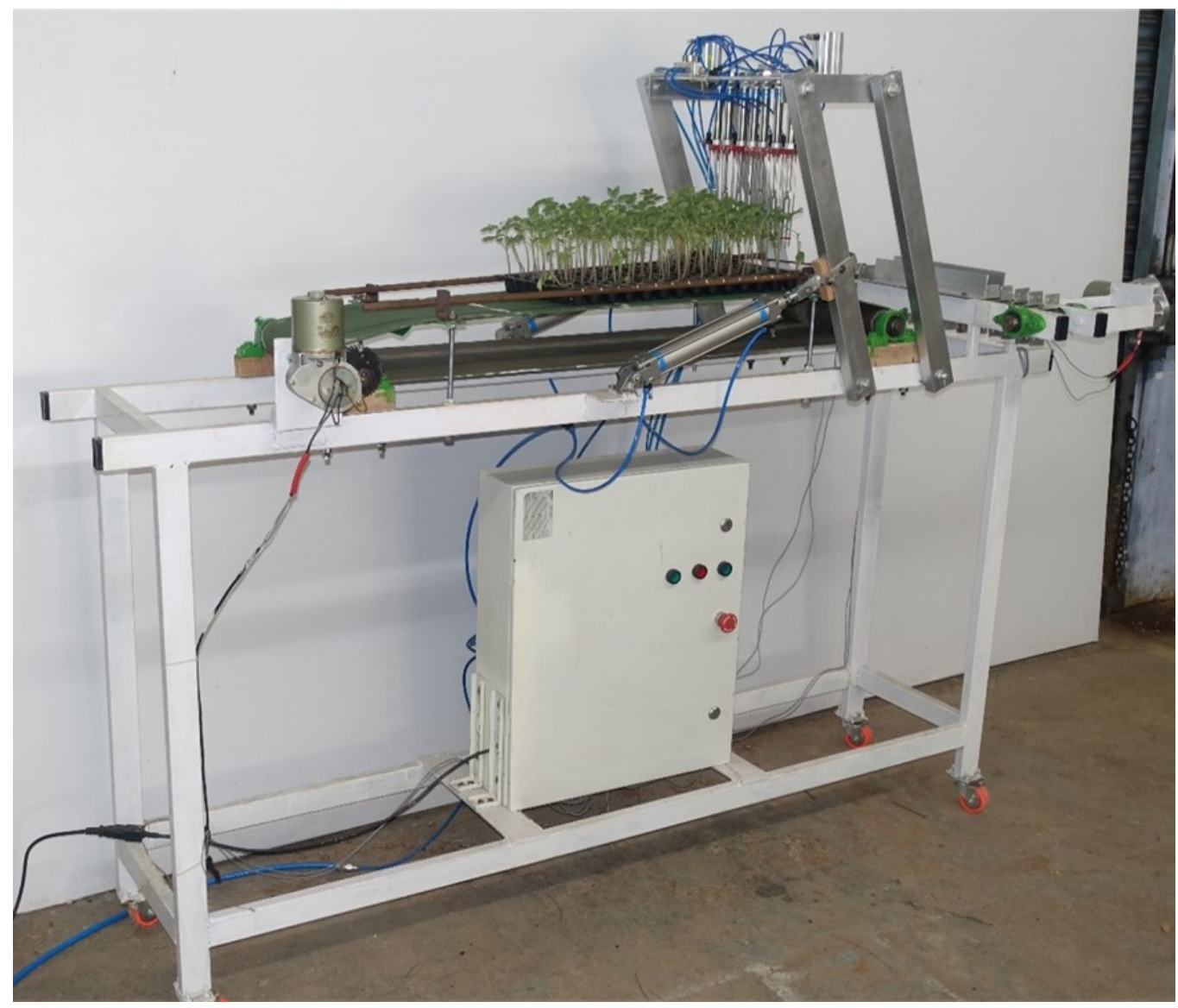

Fig. 3. Development of multiple seedling picking and dropping mechanism. 
Performance evaluation of multiple seedling picking and transplanting mechanism

The developed picking mechanism for multiple seedlings was evaluated and corresponding data were recorded with protray grown tomato, chilli and brinjal seedlings (Garg and Dixit 2002; Patil et al., 2015).

\section{Missing seedlings}

In the test trials, extraction failure and inadequate gripping between finger and growth media were considered as missing seedling and it was expressed in per cent,

MS $(\%)=N M S \times 100 / N S F$

Where,

MS = Missing seedlings, per cent

NMS = Number of missing seedlings

NSF $=$ Number of seedlings fed

\section{Damaged seedlings}

In the test trials, breakage of root lump due to overgrowth or undergrowth of seedlings were considered as damaged seedlings and it was expressed in per cent,

DS $(\%)=N D S \times 100 / \mathrm{NSF}$

Where,

DS = Damaged seedlings, per cent

NDS = Number of damaged seedlings

\section{Failure of seedlings delivered}

In the test trials, un-dropped seedlings were consid- ered as the failure of seedlings delivered and it was expressed in per cent.

FSD $(\%)=$ NFD $\times 100 / \mathrm{NSP}$

Where,

FSD = Failure of seedlings delivered, per cent

NFD = Number of seedlings failure in delivery

NSP $=$ Number of seedling picked

\section{Success rate of transplanting}

The success rate was defined as the ratio of the total number of seedling picked without missing, damage and failure of seedlings in delivery to the total number of seedlings fed. It was expressed in per cent,

$\mathrm{SR}(\%)=\mathrm{NSF}-\mathrm{NMS}-\mathrm{NDS}-\mathrm{NFD} \times 100 / \mathrm{NSF}$

Where,

$\mathrm{SR}=$ Success rate, per cent

NSF $=$ Number of seedlings fed

NMS $=$ Number of missing seedlings

NDS $=$ Number of damaged seedlings

NFD $=$ Number of seedlings failure in delivery

\section{RESULT AND DISCUSSION}

Effect of selected levels of variables on assessed parameters in vegetable seedlings

The effect of media moisture content, picking finger and angle of gripper needle on seedling missing and success rate of picking for protray grown seedlings is shown in Fig. 5. The minimum value of missing seed-
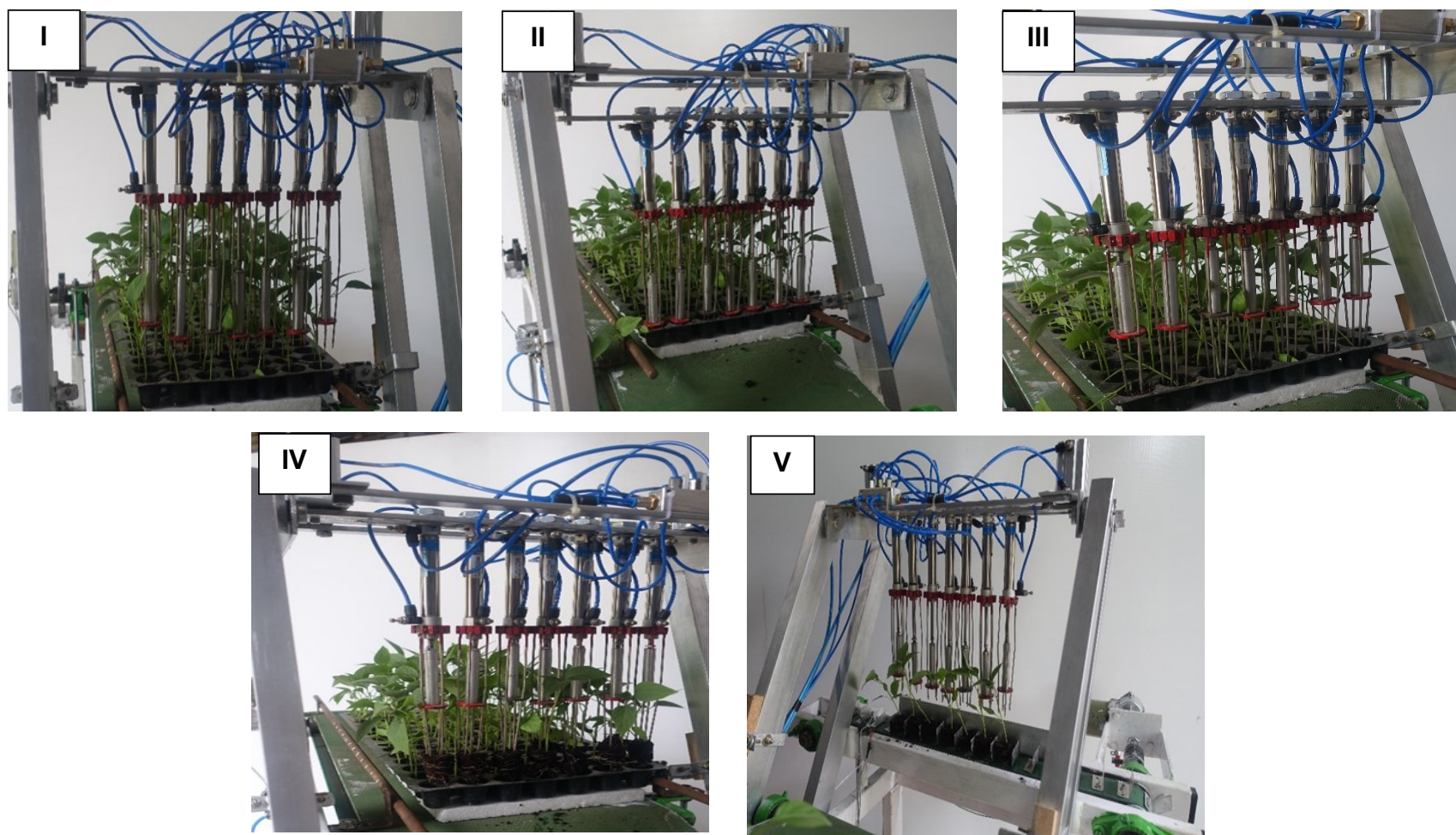

Fig. 4. Transplanting sequence of automatic picking and dropping mechanism. (I. Approaching, II. Piercing, III. Grasping, IV. Ejecting and V. Transferring and Releasing). 
Periasamy, V. et al. / J. Appl. \& Nat. Sci. 13 (SI), 47 - 54 (2021)

\begin{tabular}{cllllll}
\hline \multicolumn{2}{l}{ Table 1. ANOVA for selected levels of variables on seedlings missing. } \\
\hline S. No. & Source & df & SS & MS & F & PROB \\
\hline 1 & Total & 80 & 2049.75 & 25.62 & 238.47 & \\
2 & Media moisture content (M) & 2 & 989.97 & 494.98 & 4607.07 & $0.000^{* *}$ \\
3 & Mechanical linkage finger (F) & 2 & 735.93 & 367.96 & 3424.82 & $0.000^{* *}$ \\
4 & Angle of gripper needle $(\theta)$ & 2 & 233.48 & 116.74 & 1086.56 & $0.000^{* *}$ \\
5 & M x F & 4 & 16.37 & 4.09 & 38.10 & $0.000^{* *}$ \\
6 & F x $\theta$ & 4 & 56.15 & 14.03 & 130.66 & $0.000^{* *}$ \\
7 & M x $\theta$ & 4 & 5.81 & 1.45 & 13.53 & $0.000^{* *}$ \\
8 & M x F $\times \theta$ & 8 & 6.20 & 0.77 & 7.21 & $0.000^{* *}$ \\
9 & Error & 54 & 5.80 & 0.10 & 1.00 & \\
\hline
\end{tabular}

$\mathrm{CV}=1.34 \%,{ }^{* *}$ Significant at $1 \%$ level; ${ }^{*}$ Significant at $5 \%$ level

Table 2. ANOVA for selected levels of variables on success rate of picking seedlings .

\begin{tabular}{|c|c|c|c|c|c|c|}
\hline S. No. & Source & df & SS & MS & $\mathbf{F}$ & PROB \\
\hline 1 & Total & 80 & 4075.20 & 50.94 & 73.53 & \\
\hline 2 & Media moisture content (M) & 2 & 2002.49 & 1001.24 & 1445.29 & 0.000 ** \\
\hline 3 & Mechanical linkage finger $(F)$ & 2 & 1358.80 & 679.40 & 980.71 & 0.000 ** \\
\hline 4 & Angle of gripper needle $(\theta)$ & 2 & 592.69 & 296.34 & 427.77 & 0.000 ** \\
\hline 5 & $M \times F$ & 4 & 40.12 & 10.03 & 14.47 & $0.000 * *$ \\
\hline 6 & $\mathrm{~F} \times \theta$ & 4 & 21.62 & 5.40 & 7.80 & $0.000 * *$ \\
\hline 7 & $M \times \theta$ & 4 & 4.85 & 1.21 & 1.75 & 0.010 ** \\
\hline 8 & $M \times F \times \theta$ & 8 & 17.19 & 2.14 & 3.10 & 0.006 ** \\
\hline 9 & Error & 54 & 7.40 & 2.69 & 1.00 & \\
\hline
\end{tabular}

CV $=1.47 \%,{ }^{* *}$ Significant at $1 \%$ level; ${ }^{*}$ Significant at $5 \%$ level

ling $(6.55,3.57$ and 5.88 per cent) was registered at 18 \pm 1 per cent of growth media moisture content $\left(\mathrm{M}_{2}\right), 8^{\circ}$ of the angle of gripper needle $\left(\theta_{2}\right)$ and sliding plate cam type picking finger $\left(F_{1}\right)$ whereas, the maximum of $24.65,20.65$ and 24.15 per cent was recorded at $21 \pm 1$ per cent of growth media moisture content $\left(\mathrm{M}_{3}\right) 10^{\circ}$ of angle of gripper needle $\left(\theta_{3}\right)$ and four bar type picking finger $\left(\mathrm{F}_{3}\right)$ in tomato, chilli and brinjal seedlings respectively.

The minimum value of success rate $(75.35,79.35$ and 75.85 per cent) was registered at $21 \pm 1$ per cent of growth media moisture content $\left(\mathrm{M}_{3}\right), 10^{\circ}$ of angle of gripper needle $\left(\theta_{3}\right)$ and four bar type picking finger $\left(F_{3}\right)$ whereas, the maximum of $93.45,96.43$ and 94.12 per cent was recorded at $18 \pm 1$ per cent of growth media moisture content $\left(\mathrm{M}_{2}\right), 8^{\circ}$ of angle of gripper needle $\left(\theta_{2}\right)$ and sliding plate cam type picking finger $\left(F_{1}\right)$ in tomato, chilli and brinjal seedlings respectively. This was due to when the gripper needle was at an angle of $8^{\circ}$, the needles grasped the maximum amount of root mass whereas, the gripper could not grasp the sufficient amount of media at $6^{\circ}$ and $10^{\circ}$ angle of gripper needle $\left(\theta_{1}\right.$ and $\left.\theta_{3}\right)$ and resulted in poor extraction. A similar effect was also observed with Sivakumar and Durairaj, (2014) who developed a gravity fed automatic vegetable transplanter and concluded that the success rate of transplanting ( 90 per cent) at medium level of variables were significantly higher than other levels. Further, result was in lined with Chilur et al. (2018) who developed a auger conveyor type metering device for transplanting of vegetable seedlings raised in paper pots with success rate of 90 per cent.

Analysis of variance for media moisture content, angle of gripper needle and picking finger on seedling missing and success rate of picking seedlings is shown in Table 1 and Table 2. The individual effect of variables viz., media moisture content (M), angle of gripper needle $(\theta)$ and mechanical picking finger $(F)$ were at 1 per cent level of probability. The interaction effect of $M \times F, F \times \theta, M \times \theta$ and $M \times F \times \theta$ were significant at 1 per cent level probability. Han et al., (2018) was developed a multi-task robotic trans- 
Periasamy, V. et al. / J. Appl. \& Nat. Sci. 13 (SI), 47 - 54 (2021)

Table 3. Performance test for multiple seedlings picking and dropping mechanism.

\begin{tabular}{llllll}
\hline Seedlings & $\begin{array}{l}\text { No. of seedling } \\
\text { fed }\end{array}$ & $\begin{array}{l}\text { No. of missing } \\
\text { seedling }\end{array}$ & $\begin{array}{l}\text { No. of seed- } \\
\text { ling damage }\end{array}$ & $\begin{array}{l}\text { Seedling- } \\
\text { delivering failure }\end{array}$ & $\begin{array}{l}\text { Success ratios } \\
\text { (\%) }\end{array}$ \\
\hline Tomato & 196 & 7 & 8 & 6 & 89.28 \\
Chilli & 196 & 4 & 3 & 2 & 95.40 \\
Brinjal & 196 & 5 & 6 & 5 & 91.83 \\
\hline
\end{tabular}

planting mechanism and these experiments confirmed a significant enhancement in seedling picking and transplanting effect for greenhouse seedlings with a success rate of 90 per cent. In addition, the result was in lined with Wei et al. (2015), who tested the seedling-feeding device using maize seedling at 1 per cent level probability.

\section{Optimization of selected levels of variables based on experiments}

The combination of levels of variables that resulted in the maximum success rate of picking with minimum missing seedling for an automatic transplanting mechanism for protray grown vegetable seedlings, $M_{2} \times F_{1} x$ $\theta_{2}$, viz., $18 \pm 1$ per cent of media moisture content, sliding plate cam type picking finger and $8^{\circ}$ angle of gripper needle respectively considered as the optimized variable for the development of automatic multiple seedling picking and transplanting mechanism.

\section{Performance evaluation of multiple seedlings picking and dropping mechanism}

Performance of developed multiple seedlings picking and dropping mechanism was evaluated with optimized crop and machine variables. The transplanting frequency of developed mechanism was 2520 seedlings $\mathrm{h}^{-1}$. At the time of evaluation (Table 3), totally 196 number of seedlings were used with 98 cells protray. From the test results, the success rate of 89.28 per cent, missing seedling of 3.57 per cent, damaged seedling of 4.08 per cent, seedling delivering failure of 3.06 per cent were recorded for tomato seedlings. Similarly, in chilli and brinjal it was recorded that the success rate of 95.40 and 91.83 per cent, missing seedling of 2.04 and 2.55 per cent, damaged seedling of 1.53 and 3.06 per cent, seedling delivering failure of 1.02 and 2.55 per cent respectively were observed. Similar result was in lined with Liu et al. (2016) who optimized a transplanting actuator in a medium level of parameters with the success rate of picking was 97.6 per cent for pot type vegetable seedlings.

\section{Conclusion}

In the present study, the success rate for tomato seedlings was found to be the lowest among the three crops (Tomato, chilli and brinjal). When the number of seed- lings missed to the successful seedling extraction was compared, it was found that some seedlings did not grow due to picking up position. A total number of 7 tomato seedlings, 4 chilli seedlings and 5 brinjal seedlings were missed at the time of transplanting operation. To reduce the number of missing seedlings, it is recommended that the seedlings should be grown at the centre of the respective tray cells. Damage to tomato seedlings (8 nos.) was focused on being more as compared to other two seedlings. It was further observed that the gripper tore the seedling stem as the stem of tomato seedling was quite brittle, succumbed to easy damage during gripping by pick-up device. Hence, agronomic improvement is particularly important for automatic transplanting of protray seedling. The average seedling delivery failure was recorded as 4.33 per cent. This was due to overgrowth of seedlings, and some roots were getting struck with gripper needle. Some seedlings were stick on gripper needle due to the unfavourable moisture content of the growth media. In terms of the success rate of transplanting, the average for all the three kinds of seedlings was 92.17 per cent. The pick-up device satisfactorily grasped and removed each seedling from the protray and transported the seedling to the place where they would be precisely transplanted in the ground. As a whole, this work was able to develop a working model of vegetable seedling transplanting mechanism, which can eject seven seedlings at a time from protray cell and transfer them into slotted conveyor.

\section{ACKNOWLEDGEMENTS}

This work was supported by a grant from the Council of Scientific \& Industrial Research (CSIR), Human Resource Development Group (HRDG), CSIR Complex, Library Avenue, Pusa, New Delhi- 110012.

\section{Conflict of interest}

The authors declare that they have no conflict of interest.

\section{REFERENCES}

1. Chilur, R., Nandede, B. M., \& Tiwari, P. S. (2018). Development of an auger conveyor type metering device for transplanting of vegetable seedlings raised in paper pots. 
Tropical Agricultural Research, 29 (4), 358 - 370.

2. Garg, I.K. \& Dixit, A. (2002). Design and development of tractor operated vegetable transplanter. Paper presented in 24th workshop of All India Coordinated research scheme on Farm Implements and Machinery (ICAR) held at TNAU, Coimbatore, India.

3. Han, L., Mao, H., Kumi, F \& Hu, J. (2018). Development of a multi-task robotic transplanting work cell for greenhouse seedlings. Applied Engineering in Agriculture, 34 (2), 335342.

4. Kang, D. H., Kim, D. E., Lee, G. I., Kim, Y. H., Lee, H. J. \& Min, Y. B. (2012). Development of a vegetable transplanting robot. Journal of Bio systems Engineering, 37 (3), 201-208.

5. Kavitha, R. \& Duriasamy, V.M. (2008). Development of semi-automatic vegetable transplanter for Indian conditions. Paper presented at the agricultural and bio systems engineering for a sustainable world. International Conference on Agricultural Engineering, Hersonissos, Crete, Greece, 23-25.

6. Kumar, G. P. \& Raheman, H. (2011). Development of a walk-behind type hand tractor powered vegetable transplanter for paper pot seedlings. Journal of Bio. systems Engineering, 110 (2), 189-197.

7. Liu, J., Cao, W., Tian, D., Ouyang, Y., \& Zhao, H. (2016). Optimization experiment of transplanting actuator parameters based on mechanical property of seedling pot. Transactions of the Chinese Society of Agricultural Engineering, 32(16), 32-39.

8. Mao, H., Han, L., Hu, J. and Kumi, F. (2014). Develop- ment of a pincette-type pick-up device for automatic transplanting of greenhouse seedlings. Applied Engineering in Agriculture, 30(4), 547-556.

9. Patil, A. S., Davane, S. S. \& Malunjkar, S.V. (2015). Design, development and testing of hand held vegetable transplanter. International Journal Adv. Res., 3(1), 247253.

10. Rozan M., A. A. P., Rahul Augustine, C. J. \& Prabhu, R. M. (2016). Design and fabrication of pneumatic transplanter. International Journal for lgnited Minds, 3 (8), 93-97.

11. Sivakumar, S. \& Durairaj, C.D. (2014). Development of a gravity fed automatic vegetable transplanter with walking beam mechanism. Trends in Biosciences, 7 (6), 407-410.

12. Wei, Z., Zhaojun, N., Lianhao, L., \& Yongrui, H. (2015). Design and optimization of seedling-feeding device for automatic maize transplanter with maize straw seedlingsprouting tray. International Journal of Agricultural and Biological Engineering, 8(6), 1-12.

13. Yang, Q., L. Xu, X. Shi, A. Ibrar, Mao, H., Hu, J \& Han, L. (2018). Design of seedlings separation device with reciprocating movement seedling cups and its controlling system of the full-automatic plug seedling transplanter. Journal of Computers and Electronics in Agriculture, 147, 131145.

14. Yang, Y., Ting, K. C. \& Giacomelli, G.A. (1991). Factors affecting performance of sliding-needles gripper during robotic transplanting of seedlings. Applied Engineering in Agriculture, 7 (4), 493-498. 